Island Studies Journal, Vol. 2, No. 1, 2007, pp. 67-76

\title{
Isolation, Connectedness and the Uses of Text in Heroic-Era Antarctica: The Cases of Inexpressible and Elephant Islands
}

\author{
Elizabeth Leane
}

School of English, Journalism and European Languages

University of Tasmania, Australia

elizabeth.leane@utas.edu.au

\begin{abstract}
This article focuses on the experiences of early $20^{\text {th }}$ century expeditions trapped over winter on Antarctic islands. These explorers were in a paradoxical position, completely isolated from the world they knew but in uncomfortably close quarters with their companions. Prominent amongst the available resources that they could use to maintain sanity in these doubly trying circumstances were texts. Like the Antarctic ice, which effectively turns islands into part of the mainland, but can just as easily make an iceberg out of a seemingly stable "peece of the continent", texts were a means towards both connection and insularity for these men.
\end{abstract}

Keywords: Antarctica, exploration, isolation, text, Inexpressible Island, Elephant Island Copyright (c) 2007. Institute of Island Studies, University of Prince Edward Island, Canada.

\section{Introduction}

Antarctic travel in the early $20^{\text {th }}$ century - the so-called 'Heroic Era' of exploration of the continent - was marked by an irony: in the world's most isolated, expansive region, explorers were constantly subject to crowded, confined conditions, cooped up in ships' holds, huts, tents, and other makeshift structures, sometimes even sharing the same sleeping bag. This article looks at ways in which Heroic-Era explorers marooned on Antarctic islands used the writing and reading of text to deal with the anxieties of extreme isolation and confinement. It focuses on two well-known examples: the Northern Party of Robert F. Scott's last expedition, forced to live for over six months in an ice cave on Inexpressible Island in 1912; and members of Ernest Shackleton's Imperial TransAntarctic (the Endurance) Expedition who lived beneath two upturned boats on Elephant Island for the winter of 1916. Drawing on published and manuscript sources, the paper argues that reading and writing were put to multiple use during these expeditions, acting as both highly personal, individual acts (beating a claustrophobic situation) and public ones (increasing cohesion and decreasing tension amongst an isolated, confined community).

\section{The Ambiguous Islands of the Far South}

The island settings of these two Heroic-Era expeditions are significant. Heroic-Era explorers tended to see themselves as metaphorically inhabiting island space, whether or not they were literally doing so. As Hay notes (2006:27), this is a standard way in which 
the concept of 'island' is deployed metaphorically: "As a 'category of the mind', the island's first and obvious application is to any segment of a continental landmass characterized by isolation and remoteness". For example, the men of Douglas Mawson's Australasian Antarctic Expedition (1911-1914) located their main base on the rocky edge of the continent, but their expedition newspaper's first editorial, entitled "Marooned", begins with a comparison between the expedition, the $18^{\text {th }}$ century castaway Alexander Selkirk, and his literary counterpart Robinson Crusoe (McLean, 1913). Richard Byrd, who lived alone in a base on the Ross Ice Shelf in the winter of 1934, makes a similar comparison (1958:26). But focussing on specific, non-metaphorical Antarctic islands such as Elephant and Inexpressible allows one to highlight unusual physical characteristics which loosely parallel the paradox of simultaneous isolation and over-connectedness experienced by Heroic-Era explorers. Surveying recent work within island studies, Hay (2006:22-23) notes that paradigms of "hard-edgedness and a consequent insularity" are being replaced by an emphasis on connectedness and the permeability of boundaries. Far southern islands - physically, if not culturally - make a good case for the latter view.

Historically, the high southern latitudes were famously deceptive when it came to distinguishing land from water, and island from continent. It was not until the $20^{\text {th }}$ century that Antarctica itself, covered as it is by thick ice, was shown incontrovertibly to be a continent rather than an archipelago. Even now that Antarctica's status is clear, and its coasts and surrounding islands carefully mapped, it still throws up questions about the nature of islandness. Antarctica rapidly peels off what early explorers called 'ice-islands'. What at one minute is, to use John Donne's famous phrase, “a peece of the continent”, can at the next be an island "intire of it selfe", many miles long, taking years to melt away. Even 'real' Antarctic islands (made of rock, not ice) can have ambiguous identities. Some are permanently sutured by ice to the Antarctic coast: Ross Island, the base-camp for Scott's two expeditions and Shackleton's first, is one example; Inexpressible Island is another. Others are seasonal islands, being so during summer when the ice cover recedes.

Antarctica is often imagined as a large blank space. According to Manhire (2004:20), it is figured as "a bare canvas, a clean slate, a tabula rasa awaiting inscription and impression," the "Wide White Page" which gives his anthology of Antarctic writing its title. But the southernmost continent is also a riven space, crossed by deep crevasses, constantly moving, melting and refreezing, breaking off at its edges, surrounded by islands of rock and ice. Perhaps more than anywhere else, Antarctica alerts us to the contingent nature of islands and continents, of connectedness and isolation. The metaphor of the continent-asblank-page might neatly anticipate the territorial conquests of the Heroic Era: physical attempts at inscription. But its ambiguous islands have metaphorical power, acting as an analogy for visiting explorers who could find over-crowding when they expected isolation, and social distancing - by physical obstacles such as the noise of the wind, or emotional ones, such as personal hostility - while they were physically overly close to others.

\section{The Tensions of High-Latitude Life}

The claustrophobic conditions that Antarctic explorers experienced reached their extreme in sledging expeditions, but to some extent they also characterized daily life in expedition 
bases. Frank Wild (1937?:14-15), veteran of four Heroic-Era expeditions, writes that, despite the impression given by official accounts, "mens [sic] tempers must naturally become frayed when herded together in close quarters under the trying conditions of a Polar winter". He describes an incident during Scott's first expedition when a man became mentally unhinged, deliberately hiding in the winter drift in an attempt to launch a surprise attack on another man using a crowbar. Byrd is famous for deliberately isolating himself in Antarctica for a winter, but his account of this experience shows his awareness that one thing worse than being entirely alone in such an extreme milieu is not being entirely alone:

"In a polar camp, little things ... have the power to drive even disciplined men to the edge of insanity ... For there is no escape anywhere. You are hemmed in on every side by your own inadequacies and the crowding measures of your associates” (Byrd, 1958:16).

The two case studies which follow both included times when men became mentally unbalanced. One of Shackleton's men suffered from what, according to a fellow expeditioner, is "generally described as a 'nervous breakdown"” (Lees, quoted in Thomson, 2003:220). The Northern Party was haunted by the "spectre of mental collapse," with one man suffering a "fit of hysterical depression" (Lambert, 2002:141). Such loss of normal mental functioning was an extreme, involuntary way in which expeditioners underwent a kind of temporary escape from intolerable situations.

Recent research has largely confirmed anecdotal observations such as Wild's and Byrd's. Palinkas (2003:360) notes that the continent has "long been viewed as a natural laboratory for the study of the effects of isolation and confinement on human behaviour". These effects are not all, or always, negative; but they are significant enough to warrant attention. Palinkas cites the rate of mental disorders in wintering US staff in Antarctica at 5\%: less than that for the general population, but "noteworthy" since these personnel are initially screened for task suitability. People who fare best in these situations, Palinkas concludes (2003:357, 359), have a low need for social interaction, and so are likely to respect others' personal space. Fitzpatrick (2007:64) notes further that we should not disregard the psychological impact that the separation and crossing of an aquatic boundary may have had on island peoples, suggesting a comparison with "the effects of isolation on astronauts and scientists in Antarctica”. The men of Inexpressible and Elephant Islands were doubly disconnected, living on literal (if ambiguous) islands, and suffering metaphorical islandness via an extreme isolation imposed by their far southern locale.

An effect of prolonged time in Antarctica is increased "imaginative involvement (the ability to get involved with fantasy)” (Harrison et al., 1991:199). Barabasz (1991:209) looked at "absorption" (the "capacity for deep imaginative involvement”) in long-term isolation subjects, focussing on such activities as "... reading, creativity, daydreaming and savouring of sensory experience” (ibid.:212), finding more imaginative involvement among modern wintering staff. Subjects reported blocking out extraneous events entirely when reading a book, and to "make [their] own stories, live them in [their] mind as if they were real life” (ibid.:213). Such findings highlight the critical role that reading and writing can take on in Antarctic communities. 
If present-day Antarctic station personnel - psychiatrically screened, in continual communication with the rest of the world, relatively comfortable, and more or less assured of safe return - are considered susceptible to the stressors of confinement and isolation, one can only imagine the situation of those who lacked all these elements. Some caution, however, needs to be exercised when extrapolating research on recent expeditioners to those who travelled to Antarctica, as the conditions, expectations and cultural contexts differed in each case. Unsurprisingly, psychological studies of Heroic-Era expeditions themselves are harder to come by than analyses of more recent experiences. An exception is Mocellin and Suedfeld's content analysis of original diaries of early polar expeditions, both Arctic and Antarctic. They conclude, rather surprisingly, that "the polar experience was not generally aversive or stressful” (1991:704), as opposed to the impression given by published narratives and the assumptions made by psychological researchers. However, Mocellin and Suedfeld (1991:714) acknowledge that a diary could have had other purposes than a straightforward personal record, when they note that Robert F. Scott, writing his famous last journal, may have had an eye to a wider readership. A later article by Johnson and Suedfeld - an analysis of stress-coping mechanisms of $19^{\text {th }}$ and early $20^{\text {th }}$ century Arctic whalers and explorers - builds on this observation, noting the importance of seeking out unedited diaries when conducting content-based analysis (1996:45). None of the diaries consulted in the present analysis were published by the expeditioners themselves, but their authors were clearly concerned about the possible public presentation of their contents. As discussed below, Raymond Priestley copied out his own diaries multiple times, editing as he went; Lees' original diary is heavily annotated with large sections marked for deletion, presumably by himself, with a view to publication (his diaries were eventually published, in edited form, nearly 90 years later) (Lees, 1914-16; Thomson, 2003). These two case studies reveal that an expeditioner's diary had many potential goals, uses and readerships, and that it could be written with a view to consumption by others both within and outside the expedition, or alternatively as an intensely private record.

Even if a diary functioned in the latter capacity, however, it may not directly capture the stressors to which the men were subject. Noting that the emphasis in polar diaries was usually descriptive and avoided emotions, "especially those that did not match a heroic and stoic stereotype," Johnson and Suedfeld observe that “impression management” is only one factor in this suppression; the second is the negative impact of “dwelling on one's feelings of loneliness and longing” (1996:45, 60). Diaries can function cathartically, but writing in a diary, as well as reading others' texts, was a symbolic means of connection, of solidifying the gap between the island on which the men were imprisoned and the world back home. Thus, even if diaries did not directly express the stress of isolation and confinement (although cases such as Lees', they certainly did), they nonetheless helped to ameliorate it. Johnson and Suedfeld's article emphasizes the way in which Arctic expeditioners coped with isolation by attempting to recreate microcosms of home, through activities such as lectures, ship newspapers, sports, music and drama, religious observation, and eating and drinking (which had ceremonial as well as nutritional importance). In 'normal' Antarctic environments, on their ships and in huts, Antarctic expeditioners did exactly the same thing, as discussed elsewhere (Leane, 2003; 2005). But the deprivations and cramped environment of the ice cave on Inexpressible Island and the 
upturned boat on Elephant Island made almost all these symbolic means of connection impossible. For the two case studies examined here, text correspondingly assumed crucial significance as a means of imaginary escape from enforced isolation and insularity.

\section{Inexpressible Island}

The first case is that of Scott's Northern Party, a group of six men led by Victor Campbell (Lambert, 2002:112-150). Scott made his main base at Cape Evans, Ross Island, and originally intended for Campbell's group to explore territory to the east. An unexpected encounter with Roald Amundsen led the erstwhile 'Eastern Party' to change direction, and base themselves north of the main party, at Cape Adare in South Victoria Land. After a year of sledging and science, they were picked up at the turn of 1912 by the expedition ship and moved further south to Evans Cove. Here they depôted some supplies, and then headed off with their tents and sledges to explore further territory before being collected again at the end of summer. However, sea ice prevented the ship's return, and the men were forced to stay put, with minimal food and shelter, on an island 7 miles long and half a mile wide $(11.2 \mathrm{~km}$ by $0.8 \mathrm{~km})$, bound on the east by sea or sea ice, depending on the season, and on the west by two continental glaciers. They named the island Inexpressible (Lambert, 2002:114). They managed to survive the dark, freezing conditions of winter by building a snow cave and living on seal and penguin meat, until they could make the dangerous journey back to the main hut the following spring. The cave was $9 \times 12$ feet ( $3 \mathrm{~m}$ $\mathrm{x} 4 \mathrm{~m})$ in area, with an average height of $5 \mathrm{ft}, 6$ inches $(168 \mathrm{~cm})$ : none of the men could have stood up straight in it. The entrance was so low that some of the men had to crawl through; just inside was a latrine area, where the men, who suffered from chronic diarrhoea, spent many uncomfortable moments. The walls quickly became stained black by smoke from a blubber stove used for cooking; blubber lamps provided their only light. Famously (or infamously), Campbell observed naval hierarchies by identifying an imaginary line through the cave dividing the three crew members from the two officers and the scientist; the men implicitly agreed that what was spoken on one side could not be heard on the other (Campbell, 1988:129). Often cited as evidence of the power of British social class conventions, this decision points as much to a need to ease social isolation by following familiar practices from 'back home', in the way that Johnson and Suedfeld's Arctic whalers and explorers tried to replicate the comforts of family life.

During the winter, when darkness and freezing temperatures prevented much outdoor activity, reading formed an important occupation for the men. In their survey of polar expedition libraries, Stam and Stam (2002:113) observe that reading was a "fundamental preoccupation" of high-latitude explorers, who spent "almost as much time at their books" as they did at more stereotypical physical activities such as hauling sledges. For men in extreme situations such as the ice cave, books were far scarcer; but unstructured, unoccupied time (which Johnson and Suedfeld [1996:44] note is one of the greatest producers of stress) was abundant, and reading was correspondingly pivotal. In early 1912, living in a tent and still anticipating the return of the ship, the scientist Raymond Priestley (1912) wrote in his diary that "the worst of waiting like this is that we have only one book between the three of us - David Copperfield, by Dickens - but we are making the most of this and I have read it so thoroughly that I could easily pass a stiff examination on it”. His 
knowledge of Dickens's classic would have been second to none by the end of the following winter in the ice cave, as one of the ways in which the men kept themselves sane and occupied in the dark and eventless winter was by reading a chapter a night. Priestley's appreciation of the novel only increased: never, he writes (1910-13), had Dickens "a more dirty or more enthusiastic audience". He even reports dreaming about the novel. The regular reading of David Copperfield involved all the men in a shared narrative and provided an imaginary connection with the world back home, its many characters forming a web of connectivity which also enclosed the readers. Written to be read in serial form, David Copperfield also gave the men a sense of event and climax in a very static situation. They finished the last of its 62 chapters with great regret, but moved quickly onto the next in their small cache of books, ${ }^{1}$ a life of Robert Louis Stevenson. These regular readings were not simply a leisure activity; they were medicinal. By midwinter, the expedition doctor, Murray Levick (1912), began to worry about what he describes in his diary as a "falling off of spirits," and upped the number of chapters per day to two, which "bucked things up a good deal”. By July, they were reading three chapters of a book per day, and Priestley (1910-13) was worrying about whether their library would last the winter.

The men were also, of course, writing; the previous year, living relatively comfortably in a hut at Cape Adare, they had produced their own 'newspaper'” (another imaginary means of connection to the outside world) but now their primary outlet was their diaries. In these, the men wrote not only reflections on their experience, but also their original poetry (particularly the "sledging songs" they had composed and sung together) and quotations from books that they thought apposite or wanted to remember. One of the most avid diarists was Priestley. During the first year at Cape Adare, he not only made extensive diary entries, he then produced typed copies, editing as he went. These diaries in turn became reading material for the group in the second winter: Priestley would read them aloud along with the Dickens chapter, and the men would become nostalgic about their life in the hut the previous winter (particularly the meals). Johnson and Suedfeld (1996:49) note that isolation in polar expeditions "could sometimes be alleviated symbolically, by mail from home". Without any chance of this kind of connection, the men in the ice cave effectively sent mail to themselves by listening to Priestley's year-old observations. Later, Priestley incorporated parts of his diaries into his published account of the experience, Antarctic Adventure, and they now sit in the Scott Polar Research Institute, pored over by researchers like myself. The diaries thus evolved from private reflection, to a source of shared reminiscence, to public record, just as David Copperfield evolved from a source of individual pleasure to a shared narrative which kept the group buoyed from day to day.

\section{Elephant Island}

Similar in many ways to the experiences of Scott's Northern Party, but far more famous, is the Elephant Island episode of Shackleton's Endurance expedition. Shackleton intended to cross the Antarctic continent, but his ship became trapped by ice in the Weddell Sea before

\footnotetext{
1 They also had Boccaccio's Decameron, which was not a great success but gave its name to their blubber lamps ("Boccaccios"), William Locke's Simon the Jester, two novels by Max Pemberton, and a pocket New Testament (Priestley, 1974:257-58). Some of these books may have been depôted while the men were sledging: hence Priestley's earlier note that he had only David Copperfield to share.
} 
he could begin this attempt, and for many months remained a little wooden island amid fields of ice. After the ship was spectacularly crushed, the 28 men dragged their supplies and three boats across the sea-ice and occupied likely-looking floes, hoping they would drift closer to land. By the time they spotted Elephant Island, they were living on what Shackleton (2001:89) terms a "steadily dwindling" "floating cake of ice". The island, a mountainous, glacier-covered outcrop off the tip of the Antarctic Peninsula, 24 miles long by 12 miles wide (38km by 19km) at its widest (Stewart, 1990:1.199), was more stable than the floe but only marginally more hospitable. Shackleton and five others soon left in one of the boats in a desperate bit to reach help at another far-off island, South Georgia; the other 22 men stayed put for the winter, living under the two remaining boats, unsure when or if they would be rescued.

If books were important to Campbell's men, they became a positive fetish for Shackleton's. The men had been commanded to leave behind many of their belongings after the ship sank, but they had managed to keep a surprisingly large number of volumes. Shackleton's narrative South (1919:170) lists the remaining reading material as two books of poetry, an account of an earlier Antarctic expedition led by Otto Nordenskjöld, a penny cookery book and one or two volumes of the Encylopedia Britannica; but an examination of various diaries reveals over 15 other books, including the Iliad, Coleridge's poem “The Rime of the Ancient Mariner”, and Dickens’s Dombey and Son (James, 1914-16; Macklin, 1914-16; Lees, quoted in Thomson, 2003:247; Hurley, 1914-17; Piggott, 2004:16). The men held concerts, sing-a-longs and recitals of original verse, but they don't appear to have organized regular sessions of reading aloud as Campbell's men did; books seemed to be consumed individually, and were sometimes jealously guarded. Thomas Lees notes in his diary that he has with him a book that he kept "absolutely secret" in his sleeping bag for six months, throughout the journey across the sea-ice. He also observes that the Australian photographer Frank Hurley has a book he is "not disposed to lend ... out" (quoted in Thomson, 2003:248). ${ }^{2}$ Hurley's own enthusiasm for a good read is evident from his diary: "I have been reading Nordenskjöld all day, \& so similar to our own position is his narrative that I became so interested \& absorbed that I actually felt it was our party that was being rescued by the Uruguay". Hurley was here experiencing the "imaginative involvement" identified by Barabasz in modern expeditioners (1991:213). Frank Wild, leader of the group in Shackleton's absence, worried about this kind of reaction: he didn't like the men to read Nordenskjöld's book due to the close parallels with their own situation (Piggott, 2004:16). Nordenskjöld's men had also spent a winter in a makeshift hut, using their upturned sledge rather than a boat as a roof. The account would have made Shackleton's men appreciate at least one advantage of their situation: where they had over a dozen books, the earlier castaways were reduced to reading labels on their tins of condensed milk and boiled beef, and repeating to each other what they could remember of The Three Musketeers and The Count of Monte Cristo (Nordenskjöld \& Andersson, 1977:464). If

\footnotetext{
${ }^{2}$ Both books were on loan from a benefactor in England. Lees claims that he kept his in secret to ensure he could return it to its owner, and suggests that Hurley did the same. There may have been other reasons why the expeditioners guarded their books so carefully, however.
} 
Wild had had the benefit of current psychological research, he could have realized that reading Nordenskjöld's account might have offered the benefits of "downward social comparison", meaning "making oneself feel better by talking about people whose fate was even worse” (Johnson \& Suedfeld, 1996:49). But he did recognize the importance of access to text, rationing out the volumes of the Encyclopedia: Lees notes that the men became erudite on topics starting with A, P, M, E and S (quoted in Thomson, 2003:224).

Like Campbell's men, the Elephant Islanders were also avid writers. Lees kept a detailed diary, remarking in it that "One might think that there was nothing to write about when one is leading such an inert life as ours, but I find that one does such a lot of thinking that the trouble is to eliminate the purely conjectural matter" (quoted in Thomson 2003:250-51). Diaries not only contained reflections and descriptions; they also served as a forum for creativity. Hurley used his to record a number of topical verses he composed during his time on the island, including “Our Home on Elephant Isle”. Such poems and songs were significant tension releases for polar expeditioners. They were usually amusing and, under the guise of humour, could make points that might be explosive if posed directly. The unpopular Lees, for example, was a butt of several verses. Hurley (1914-17) wrote a song teasing him over his snoring and his hoarding of food; Alexander Macklin recited scathing verses about his unscrupulousness in winning a food bet (quoted in Thomson, 2003:242); Leonard Hussey wrote what Lees terms "a particularly heartless piece of poetry" partly inspired by the latter's disagreement with Macklin over floor space (ibid.:238-9). Lees observes candidly in his diary that "It is only natural that one should occasionally get a bit fed up with one another, considering our fearful congestion” (ibid.:239). Lees was both annoyed and relieved by texts: the community used them to express disapproval of his behaviour, while he used them to express private thoughts and opinions. In the case of his hidden book, Lees retained a means of imaginative escape that was his alone.

\section{Conclusion}

The experiences of the men marooned on Inexpressible and Elephant Islands highlight the multiple uses and purposes of reading and writing in polar expeditions. Reading could be an intensely personal activity, a way of connecting with the world back home and escaping present privations through imaginative involvement. But it could also be an activity that drew the isolated group together, making the involvement a communal one. The upkeep of a diary was similarly multi-purpose. At the base level, it was an important practical component of polar exploration, providing a record of events for later reference. Another obvious purpose was to allow the writer to vent his feelings, to express the frustration, depression or despair that couldn't be spoken aloud. Yet diaries could also be public Priestley's is clearly written with an eye to consumption by others, and he eventually used it as a way to sustain his companions' emotional needs as well as his own. Text acted like ice in Heroic-Era expeditions, at times insulating expedition members from those around them, calving off little imaginative islands on which they could maroon themselves; and at other times solidifying the gaps between them. 


\section{References}

Barabasz, M. (1991) 'Imaginative Involvement in Antarctica: Applications to Life in Space’ in A.A. Harrison, Y.A. Clearwater \& C.P. McKay (eds.) From Antarctica to Outer Space: Life in Isolation and Confinement, New York, Springer-Verlag, pp. 209-215.

Byrd, R. (1938/1958) Alone, London, Harborough.

Campbell, V. (1988) The Wicked Mate: The Antarctic Diary of Victor Campbell, edited by H G.R. King, Bluntisham, Huntingdon, Bluntisham Books.

Fitzpatrick, S.M. (2007) 'Archaeology’s Contribution to Island Studies', Island Studies Journal, Vol. 2, No. 1, pp. 57-80.

Hay, P. (2006) ‘A Phenomenology of Islands', Island Studies Journal, Vol. 1, No. 1, pp. 19-42.

Hurley, F. (1914-17) Diaries, 5 Nov. 1914 - 25 April 1917, Sydney, Mitchell Library, ML ref. ML MSS 389/2: CY Reel 1423.

James, R. (1914-16) Journals kept during the British Imperial Antarctic Expedition, 191416, Cambridge, Scott Polar Research Institute, MS 370/1-5.

Johnson, P.J. \& Suedfeld, P. (1996) 'Coping with Stress through the Microcosms of Home and Family among Arctic Whalers and Explorers', The History of the Family, Vol. 1, No. 1, pp. 41-62.

Lambert, K. (2002) Hell with a Capital 'H': An Epic Story of Antarctic Survival, London, Pimlico.

Leane, E. (2005) 'The Adelie Blizzard: Neglected Newspaper of the Australasian Antarctic Expedition (1911-14)’, Polar Record, Vol. 41, No. 1, pp 11-20.

Leane, E. (2003) 'Antarctic Theatricals: The Frozen Farce of Scott's First Expedition', Theatre Notebook, Vol. 57, No. 3, pp. 143-57.

Lees, T. O. (1914-16). Antarctic Journal, Alexander Turnbull Library, Micro-MS-0180.

Levick, G. M. (1912) Journals kept on the Northern Party of the British Antarctic Expedition, 1910-1913. 9 January -14 November 1912, Vol. 2, Rough Journal, 29 March 28 September 1912, Cambridge, Scott Polar Research Institute, MS 1423/2.

Macklin, A. (1914-16) Diaries, Cambridge, Scott Polar Research Institute, MS 1589.

Manhire, B. (ed.) (2004) The Wide White Page: Writers Imagine Antarctica, Wellington, New Zealand, Victoria University Press. 
McLean, A. (1913) 'Marooned', Adelie Blizzard (unpublished manuscript), Vol. 1, Adelaide, Mawson Collection, South Australian Museum, 184AAE/1, pp. 1-2.

Nordenskjöld, O. \& Andersson, J.G. (1905/1977) Antarctica, or, Two Years amongst the Ice of the South Pole, London, Hurst.

Palinkas, L.A. (2003) 'The Psychology of Isolated and Confined Environments: Understanding Human Behaviour in Antarctica', American Psychologist, Vol. 58, No. 5, pp. 353-363.

Piggott, J. (2004) 'Shackleton's Men: Life on Elephant Island', James Caird Society Journal, Vol. 2, pp. 10-18.

Priestley, R.E. (1914/1974) Antarctic Adventure: Scott's Northern Party, Carlton, Australia, Melbourne University Press.

Priestley, R.E. (1912) Copy of Part of General Diary, British Antarctic Expedition, 191013: 1 Jan - 3 Oct 1912, unbound typescript, Cambridge, Scott Polar Research Institute, MS 298/6/3.

Priestley, R.E. (1910-13) Journals kept during the British Antarctic Expedition, 1910-13, 3 Vols., holograph, Cambridge, Scott Polar Research Institute, MS 298/14/1-3.

Shackleton, E. (2001; orig. 1919) South: The Story of Shackleton's Last Expedition 19141917, Edinburgh, Birlinn.

Stam, David \& Stam, Deirdre (2002) 'Silent Friends: Books and Reading on Polar Expeditions' in K. Caning \& V.S. Jakobsen (eds.) Poles Apart: Poles On-Line, Proceedings of the 19th Polar Libraries Colloquy, June, Copenhagen, Danish Polar Centre.

Stewart, J. (1990) Antarctica: An Encyclopaedia, 2 Vols., Jefferson NC and London, McFarland.

Stonehouse, B. (ed.) (2002) Encyclopaedia of Antarctica and the Southern Oceans, Chichester, Wiley.

Thomson, J. (2003) Elephant Island and Beyond: The Life and Diaries of Thomas Orde Lees, Norwich, Erskine Press, \& Bluntisham, Huntingdon, Bluntisham Books.

Wild, F. (1937?) Papers Vol. 2: Transcript of Memoirs, Sydney, Mitchell Library, ML ref. ML MSS 2198/2: CY Reel 15. 